\title{
EWSR1/ATF1 Fusion Gene Type 2
}

National Cancer Institute

\section{Source}

National Cancer Institute. EWSR1/ATF1 Fusion Gene Type 2. NCI Thesaurus. Code C99220.

A fusion gene ( $\sim 3.0 \mathrm{~kb})$ that results from a chromosomal translocation $\mathrm{t}(12 ; 22)(\mathrm{q} 13 ; \mathrm{q} 12)$

which fuses the first 7 exons of the EWSR1 gene on the 5' side of exon 5 of the ATF1 gene. This rearrangement is associated with both malignant clear cell sarcoma of the soft tissue and angiomatoid fibrous histiocytoma. 